\title{
ANALISIS BIOAUTOGRAFI DENGAN KROMATOGRAFI LAPIS TIPIS PADA EKSTRAK ETANOL DAUN Caesalpinia sumatrana ROXB. TERHADAP BAKTERI PENYEBAB INFEKSI NOSOKOMIAL
}

\author{
Yadi Yasir*, Yuniati Yuniati, Swandari Paramita, Mona Zubaidah, \\ Abdul Mu’ti, Danial Danial \\ Fakultas Kedokteran Universitas Mulawarman Samarinda \\ *Corresponding author email: dryadi02@yahoo.com
}

\begin{abstract}
Nosocomial infections are a major health problem in Indonesia; this is mainly due to their resistance to antibiotics. Based on this, the quest for new sources of natural based antimicrobial drugs is necessary. This study was conducted to test the potential of Caesalpinia sumatrana Roxb. leaves extract which is traditionally used as a medicine by Dayak tribe for wounds and skin infection. Bioautography analysis of plant extract done by thin layer chromatography (TLC) against Pseudomonas aeruginosa, Proteus mirabilis, Staphylococcus aureus and Methicillin Resistant Staphylococcus aureus (MRSA). Results of research on extracts of C. sumatrana discovered containing sugar compounds which have potential antimicrobial activity against all bacteria; alkaloid compounds which have potential antimicrobial activity against $S$. aureus and MRSA; terpene-steroid compounds which have potential antimicrobial activity against P. mirabilis, S. aureus and MRSA; and flavonoid compounds which have potential antimicrobial activity against $S$. aureus. The conclusion of this study is the secondary metabolites of $C$. sumatrana leaves extract can inhibit the growth of bacteria that cause nosocomial infections.
\end{abstract}

Keywords: Caesalpinia sumatrana, antimicrobial, bioautography, thin layer chromatography

\begin{abstract}
ABSTRAK
Infeksi nosokomial merupakan masalah kesehatan utama di Indonesia, hal ini terutama disebabkan adanya resistensi terhadap antibiotik. Berdasarkan hal tersebut, maka upaya pencarian sumber antimikroba baru berbasis tumbuhan obat perlu dilakukan. Penelitian ini dilakukan untuk menguji potensi ekstrak daun Caesalpinia sumatrana Roxb. yang secara tradisional digunakan etnis Dayak sebagai obat luka dan sakit kulit. Analisis bioautografi ekstrak tumbuhan dilakukan dengan kromatografi lapis tipis (KLT), terhadap Pseudomonas aeruginosa, Proteus mirabilis, Staphylococcus aureus dan Methicillin Resistant Staphylococcus aureus (MRSA). Hasil penelitian pada ekstrak C. sumatrana ditemukan golongan senyawa mengandung gula memiliki potensi aktivitas antimikroba terhadap keempat bakteri; senyawa golongan alkaloid memiliki potensi aktivitas antimikroba terhadap S. aureus dan MRSA; senyawa golongan terpensteroid memiliki potensi aktivitas antimikroba terhadap P. mirabilis, S. aureus dan MRSA; dan senyawa golongan flavonoid memiliki potensi aktivitas anti mikroba terhadap $S$. aureus. Kesimpulan penelitian ini adalah hasil metabolit sekunder ekstrak daun $C$. sumatrana dapat menghambat pertumbuhan bakteri penyebab infeksi nosokomial.
\end{abstract}

Kata kunci: Caesalpinia sumatrana, antimikroba, bioautografi, kromatografi lapis tipis

Submitted on: 4 April $2017 \quad$ Accepted on: 7 July 2017

DOI: https://doi.org/10.25026/jsk.v1i7.57

\section{PENDAHULUAN}

Infeksi nosokomial disebut juga sebagai HCAI (health care-associated infection), merupakan infeksi yang terjadi pada pasien selama menjalani proses perawatan di rumah sakit atau pelayanan kesehatan lainnya, yang tidak muncul atau dalam masa inkubasi pada saat pasien mulai opname. Infeksi nosokomial menyebabkan meningkatnya masalah resistensi antibiotik (WHO, 2017 ${ }^{\mathrm{a}}$ ). Diperkirakan setiap tahun di Amerika 
Serikat ada 1,7 juta kasus infeksi nosokomial yang terjadi, yang menyebabkan hampir 99.000 kasus kematian. Bakteri yang menjadi perhatian penting terkait infeksi nosokomial di rumah sakit adalah Methicillin Resistant Staphylococcus aureus (MRSA), Staphylococcus aureus, Pseudomonas aeruginosa dan Proteus mirabilis. Infeksi nosokomial dapat menyebabkan pneumonia berat dan infeksi pada saluran kemih, aliran darah serta organ tubuh lainnya. Sebagian besar kuman sulit untuk ditangani dengan antibiotik biasa, masalah resistensi antibiotik mempersulit upaya pengobatan pasien tersebut (Bonilla dan Muniz, 2009).

World Health Organization (WHO)

telah mengeluarkan daftar patogen prioritas untuk meningkatkan upaya riset pencarian antibiotik baru, guna mengatasi masalah resistensi antibiotik. Dalam daftar patogen prioritas tersebut terdapat MRSA yang mendapat prioritas tinggi untuk riset pencarian antibiotik baru terhadapnya (WHO, 2017 ). Salah satu sumber antibiotik baru adalah tumbuhan obat yang berasal dari alam. Riset menunjukkan bahwa komponen aktif dalam tumbuhan obat memiliki efek antimikroba yang berbeda mekanisme kerjanya dari antibiotik yang sudah ada selama ini. Hal ini menunjukkan potensi tumbuhan obat dalam mengatasi masalah resistensi antibiotik (Ganapathy dan Karpagam, 2016).

Salah satu tumbuhan obat yang memiliki potensi efek antimikroba adalah Caesalpinia sumatrana Roxb. Tumbuhan ini termasuk dalam famili Fabaceae. Tumbuhan ini terutama ditemukan di Asia Tenggara dan dikenal dengan nama umum pohon cakar kucing. Sinonim tumbuhan ini adalah Mezoneuron koordersii Backer, Mezoneuron peekelii Harms, Mezoneuron sulfureum Miq., dan Mezoneuron sumatranum (Roxb.) Wight
\& Arn. (The Plant List, 2013). Etnis Dayak di Kalimantan Utara menggunakan $C$. sumatrana untuk obat luka dan sakit kulit (Ismail et al, 2015).

Spesies Caesalpinia lain yang cukup dikenal di Indonesia adalah $C$. sappan, dengan nama umum pohon secang atau sepang. Kulit batang kayu $C$. sappan sudah sejak lama dikenal sebagai bahan pewarna alami dan bahan obat tradisional (Batubara dan Mitsunaga, 2013). Selain itu juga ada $C$. pulcherrima, dikenal dengan nama bunga merak. Tumbuhan ini lebih sering menjadi penghias pekarangan rumah karena bunganya memiliki warna mencolok (Zanin et al, 2012). Berbeda dengan $C$. sappan dan $C$. pulcherrima yang lebih terkenal, $C$. sumatrana tidak banyak diketahui penggunaannya sebagai obat tradisional secara luas. Berdasarkan hal tersebut diatas maka penelitian ini bermaksud untuk melihat analisis bioautografi ekstrak etanol daun $C$. sumatrana dengan kromatografi lapis tipis (KLT), terhadap $P$. aeruginosa, $P$. mirabilis, S. aureus dan MRSA.

\section{METODE PENELITIAN}

\section{Waktu dan Tempat}

Penelitian dilakukan pada bulan Mei hingga Oktober 2016. Penelitian ini telah memperoleh kelayakan etik dari Komisi Etik Penelitian Kedokteran dan Kesehatan, Fakultas Kedokteran Universitas Mulawarman. Lokasi pengambilan sampel tumbuhan obat dilakukan di Kabupaten Mahakam Ulu, Kalimantan Timur. Identifikasi tumbuhan obat dilakukan oleh Laboratorium Dendrologi, Fakultas Kehutanan Universitas Mulawarman. Pengolahan sampel tumbuhan obat dilakukan di Laboratorium Farmakologi, Fakultas Kedokteran Universitas Mulawarman. Uji bioautografi KLT dilakukan di 
Laboratorium Mikrobiologi, Fakultas Kedokteran Universitas Mulawarman.

\section{Pembuatan Ekstrak Tumbuhan Obat}

Simplisia yang telah dihaluskan lalu dimaserasi dengan pelarut etanol. Pada penelitian ini digunakan pelarut etanol absolut. Untuk pembuatan ekstrak, dimasukkan satu bagian serbuk kering simplisia ke dalam maserator (ditimbang botol maserasi sebelum dimasukkan simplisia dan ditimbang ulang setelah dimasukkan simplisia), ditambahkan 10 bagian pelarut (ukur volume sebelum dimasukkan). Selanjutnya direndam selama 6 jam sambil sesekali diaduk (menggunakan shaker orbital dengan kecepatan $20 \mathrm{rpm}$ selama 10 menit) pada suhu kamar, kemudian didiamkan selama 18 jam. Maserat dipisahkan dengan cara filtrasi dengan menggunakan kertas saring Whatman. Proses penyarian diulangi dua kali dengan jenis dan jumlah pelarut yang sama. Semua maserat dikumpulkan, kemudian diuapkan dengan vakum rotavapor suhu $50^{\circ} \mathrm{C}$ hingga diperoleh ekstrak kental. Kemudian ekstrak yang didapat dikeringkan lebih lanjut dengan dimasukkan dalam desikator yang berisi silika gel biru dalam oven suhu $50^{\circ} \mathrm{C}$. Setelah didapatkan ekstrak kering, dihitung rendemen yang diperoleh, yaitu persentase bobot (b/b) antara rendemen dengan bobot serbuk simplisia yang digunakan dengan cara penimbangan. Ekstrak kering disimpan dalam kulkas $-20^{\circ} \mathrm{C}$ sebelum dilakukan penelitian lebih lanjut (Depkes RI, 2008).

\section{Pembuatan Suspensi Bakteri}

Pada penelitian ini digunakan 4 jenis bakteri sebagai bakteri uji yang diketahui sering terkait dengan infeksi nosokomial. Bakteri tersebut adalah $P$. aeruginosa ATCC 15442, $S$. aureus ATCC 25923, S. aureus (MRSA) ATCC 33591, dan 1 bakteri strain lokal yaitu
P. mirabilis. Masing-masing strain bakteri dibiakkan dalam medium Muller-Hinton broth selama 18 sampai 24 jam. Bakteri yang telah diinkubasi ini kemudian dimasukkan kembali ke dalam media Muller-Hinton broth (1,5 strength) kemudian ditentukan konsentrasinya dengan menggunakan spektrofotometer pada panjang gelombang $625 \mathrm{~nm}$ dengan rentang nilai OD 0,08-0,13 setara dengan standar McFarland 0,5 yang selanjutnya digunakan untuk penentuan kadar hambat minimum.

\section{Kromatografi Lapis Tipis}

Lempeng KLT yang akan digunakan dipanaskan dalam oven pada suhu $100^{\circ} \mathrm{C}$ selama 30 menit. Ekstrak etanol daun $C$. sumatrana ditotolkan pada lempeng KLT menggunakan pipa kapiler, dibiarkan beberapa menit hingga kering lalu dimasukkan ke dalam TLC Chamber (Camag) yang sudah jenuh dengan cairan pengelusi. Dibiarkan terelusi sampai batas lempeng kromatogram yang telah ditentukan. Lempeng dikeluarkan dari TLC Chamber, lalu noda yang tampak diamati di bawah sinar UV dengan panjang gelombang 254 dan $365 \mathrm{~nm}$, kemudian dilakukan penentuan nilai Retardation Factor (Rf). Kromatogram dibuat minimal 5 rangkap untuk setiap eluen yang digunakan, 4 pelat kromatogram akan digunakan untuk identifikasi 4 golongan senyawa yaitu golongan senyawa mengandung gula, golongan alkaloid, golongan terpensteroid dan golongan flavonoid. Pelat KLT yang tersisa digunakan untuk bioautografi KLT untuk melakukan evaluasi aktivitas antimikroba. Pada penelitian ini digunakan 4 macam eluen yang berbeda yaitu; butanol/ asam asetat/ air dengan perbandingan 4:1:5, n-heksan/ etil asetat dengan perbandingan 4:1, kloroform/ etil asetat/ asam formiat 
dengan perbandingan $0,5: 9: 0,5$ dan etil asetat/ metanol/ air dengan perbandingan $6: 4: 2$. Setiap cuplikan berisi $10 \mathrm{mcg}$ yang diambil dari $2 \mu \mathrm{L}$ ekstrak tumbuhan obat yang telah dilarutkan dalam pelarut etanol 96\% dengan konsentrasi $10 \mathrm{mg} / \mathrm{ml}$.

\section{Bioautografi Kromatografi Lapis Tipis}

Pada penelitian ini metode yang digunakan adalah bioautografi agar overlay. Medium agar broth sebanyak 10 $\mathrm{mL}$ yang sudah dicampur $1 \mathrm{~mL}$ suspensi bakteri bakteri uji. $P$. aeruginosa, $P$. mirabilis, $S$. aureus dan MRSA yang telah disiapkan dalam media agar dituang untuk melapisi lempeng KLT yang sebelumnya telah dielusi. Setelah itu lempeng KLT tersebut diinkubasikan pada suhu $37{ }^{\circ} \mathrm{C}$ selama $18-24$ jam. Kemudian dilakukan pencatatan zona hambat yang terbentuk.

\section{Analisis Statistik}

Data yang terdistribusi normal dan bervarian homogen dianalisis secara statistik parametrik menggunakan ANOVA. Data yang tidak terdistribusi normal dan tidak bervarian homogen dianalisis secara statistik non parametrik menggunakan uji Kruskal Wallis. Homogenitas dan normalitas data diuji dengan Kolmogorov-Smirnov. Pengolahan data dilakukan dengan SPSS Statistics 16.0. Perbedaan dikatakan signifikan jika $\mathrm{p}<0.05$.

\section{HASIL DAN PEMBAHASAN}

\section{Kromatografi Lapis Tipis (KLT)}

Hasil KLT ekstrak daun $C$. sumatrana dengan menggunakan berbagai fase gerak menunjukkan pemisahan dan kenaikan noda yang bervariasi. Pada ekstrak daun $C$. sumatrana ditemukan noda-noda pada pelat KLT yang terpisah dengan cukup baik dengan menggunakan eluen kloroform/ etil asetat/ asam formiat $(0,5: 9: 0,5)$. Hal ini berarti bahwa senyawa-senyawa pada ekstrak etanol daun $C$. sumatrana adalah senyawasenyawa polar atau semi non-polar karena kloroform, etil asetat dan asam formiat adalah pelarut polar. Nilai Rf kromatogram ekstrak etanol daun $C$. sumatrana ditunjukkan pada tabel 1 .

Identifikasi terpenoid dan steroid dilakukan dengan menggunakan pereaksi Lieberman-Burchard. Timbulnya warna merah hingga ungu menandakan adanya triterpenoid, sedangkan warna hijau menunjukkan adanya senyawa steroid. Identifikasi senyawa golongan flavonoid dilakukan dengan menggunakan pereaksi $\mathrm{AlCl}_{3}$. Bila timbul warna hijau kekuningan pada penyemprotan menunjukkan keberadaan senyawa flavonoid pada KLT. Setelah pemberian pereaksi untuk mengidentifikasi 4 golongan senyawa yaitu golongan senyawa mengandung gula, alkaloid, terpen-steroid dan flavonoid ditemukan bahwa ekstrak etanol daun $C$. sumatrana memiliki semua golongan senyawa ini. Profil kromatogram ekstrak etanol daun C. sumatrana setelah pemberian pereaksi ditunjukkan pada tabel 2 .

\section{Bioautografi KLT}

Hasil bioautografi KLT pada ekstrak etanol daun $C$. sumatrana ditemukan golongan senyawa mengandung gula memiliki potensi aktivitas antimikroba terhadap $P$. aeruginosa, $P$. mirabilis, $S$. aureus dan MRSA; senyawa golongan alkaloid memiliki potensi aktivitas antimikroba terhadap S. aureus dan MRSA; senyawa golongan terpen-steroid memiliki potensi aktivitas antimikroba terhadap $P$. mirabilis, S. aureus dan MRSA; dan senyawa golongan flavonoid memiliki potensi aktivitas anti mikroba terhadap $S$. aureus. Tabel 3 menunjukkan hasil 
analisis golongan senyawa yang memiliki aktivitas antimikroba pada ekstrak etanol daun $C$. sumatrana.

Pada pemeriksaan bioautografi ditemukan bahwa ekstrak etanol daun $C$. sumatrana dapat menghambat pertumbuhan semua bakteri yang diujikan yaitu $P$. aeruginosa, $P$. mirabilis, S. aureus dan MRSA. Bioautografi merupakan metode yang spesifik untuk mendeteksi bercak pada kromatogram hasil KLT yang mempunyai aktivitas antimikroba. Dasar metode ini adalah tehnik difusi agar, dimana senyawa antimikroba berpindah dari plat KLT ke medium agar yang telah mengandung bakteri. Setelah melalui proses inkubasi selama 24 jam, akan tampak zona jernih yang tidak ditumbuhi bakteri pada titik-titik tertentu yang mengandung senyawa antimikroba (Nelson dan Cox, 2005).

Sepanjang pengetahuan peneliti, ini adalah studi pertama yang meneliti tentang efek farmakologis dari ekstrak etanol daun $C$. sumatrana. Penelitian telah banyak dilakukan terhadap spesies Caesalpinia yang lain, yaitu C. sappan dan C. pulcherrima.

Tabel 1. Nilai Rf kromatogram ekstrak etanol daun C. sumatrana

\begin{tabular}{|c|c|c|c|c|c|}
\hline \multirow[b]{2}{*}{ Sinar } & \multirow[b]{2}{*}{ Noda } & \multicolumn{4}{|c|}{ Nilai Rf } \\
\hline & & $\begin{array}{c}\text { butanol/ asam } \\
\text { asetat/ air } \\
(4: 1: 5)\end{array}$ & $\begin{array}{c}\text { n-heksan/ etil } \\
\text { asetat } \\
(4: 1)\end{array}$ & $\begin{array}{c}\text { kloroform/ etil asetat/ } \\
\text { asam formiat }(0,5: 9: 0,5)\end{array}$ & $\begin{array}{c}\text { etil asetat/ methanol/ } \\
\text { air }(6: 4: 2)\end{array}$ \\
\hline \multirow{3}{*}{ UV 254} & 1 & 0,88 & - & 0,89 & 0,69 \\
\hline & 2 & - & - & - & 0,79 \\
\hline & 3 & - & - & - & 0,90 \\
\hline \multirow{5}{*}{ UV 365} & 1 & 0,42 & 0,20 & 0,11 & 0,75 \\
\hline & 2 & 0,50 & 0,28 & 0,80 & 0,81 \\
\hline & 3 & 0,67 & 0,39 & 0,86 & 0,94 \\
\hline & 4 & 0,77 & - & 0,92 & - \\
\hline & 5 & 0,88 & - & - & - \\
\hline
\end{tabular}

Tabel 2. Profil kromatogram ekstrak etanol daun C. sumatrana setelah pemberian pereaksi

\begin{tabular}{ccccc}
\hline \multirow{2}{*}{ Golongan } & \multicolumn{4}{c}{ Nilai Rf } \\
\cline { 2 - 5 } & $\begin{array}{c}\text { butanol/ asam } \\
\text { asetat/ air (4:1:5) }\end{array}$ & $\begin{array}{c}\text { etil asetat/ metanol/ } \\
\text { air }(6: 2: 4)\end{array}$ & $\begin{array}{c}\text { kloroform/ etil } \\
\text { asetat/ asam formiat } \\
(0,5: 9: 0,5)\end{array}$ & $\begin{array}{c}\text { n-heksan/ etil } \\
\text { asetat } \\
(4: 1)\end{array}$ \\
\hline $\begin{array}{c}\text { Senyawa } \\
\text { mengandung gula }\end{array}$ & 0,18 & 0,78 & 0,78 & 0,22 \\
(UV365) & 0,82 & 0,82 & 0,82 & 0,22 \\
\hline $\begin{array}{c}\text { Senyawa alkaloid } \\
\text { (sinar tampak) }\end{array}$ & 0,94 & 0,94 & 0,13 & 0,16 \\
\hline Senyawa terpen- & 0,42 & 0,82 & 0,82 & 0,22 \\
steroid (UV365) & & 0,89 & 0,84 & 0,33 \\
\hline $\begin{array}{c}\text { Senyawa flavonoid } \\
\text { (UV365) }\end{array}$ & 0,78 & 0,82 & 0,94 & 0,22 \\
\hline
\end{tabular}


Analisis bioautografi dengan kromatografi lapis tipis pada ekstrak etanol daun Caesalpinia sumatrana roxb. Terhadap bakteri penyebab infeksi nosokomial

Tabel 3. Hasil analisis golongan senyawa yang memiliki aktivitas antimikroba pada ekstrak etanol daun $C$. sumatrana

\begin{tabular}{|c|c|c|c|c|c|}
\hline \multirow[b]{2}{*}{ Golongan Senyawa } & \multirow[b]{2}{*}{ Jenis Bakteri } & \multicolumn{4}{|c|}{ Nilai Rf Pada Zona Hambat } \\
\hline & & $\begin{array}{l}\mathrm{BAA}^{(\mathrm{a})} \\
(4: 1: 5)\end{array}$ & $\begin{array}{c}\text { EMA }^{(\mathrm{b})} \\
(6: 2: 4)\end{array}$ & $\begin{array}{c}\text { KEAS }^{(\mathrm{c})} \\
(0,5: 9: 0,5)\end{array}$ & $\begin{array}{c}\mathrm{NEA}^{(\mathrm{d})} \\
(4: 1)\end{array}$ \\
\hline \multirow[t]{4}{*}{ mengandung gula ${ }^{(\mathrm{e})}$} & P. aeruginosa & - & 0,78 & 0,78 & - \\
\hline & $M R S A$ & - & 0,82 & 0,82 & - \\
\hline & S. aureus & - & - & - & 0,22 \\
\hline & P. mirabilis & - & 0,82 & 0,82 & - \\
\hline \multirow[t]{4}{*}{ alkaloid $^{(\mathrm{f})}$} & P. aeruginosa & - & - & - & - \\
\hline & $M R S A$ & - & - & 0,82 & - \\
\hline & S. aureus & - & - & - & 0,22 \\
\hline & P. mirabilis & - & - & - & - \\
\hline \multirow[t]{4}{*}{ terpen-steroid $^{(g)}$} & P. aeruginosa & - & - & - & - \\
\hline & MRSA & - & 0,82 & - & - \\
\hline & S. aureus & - & - & - & 0,22 \\
\hline & P. mirabilis & - & 0,82 & - & - \\
\hline \multirow[t]{4}{*}{ flavonoid $^{(\mathrm{h})}$} & P. aeruginosa & - & - & - & - \\
\hline & $M R S A$ & - & - & - & - \\
\hline & S. aureus & 0,89 & - & - & 0,22 \\
\hline & P. mirabilis & - & - & - & - \\
\hline
\end{tabular}

Keterangan:

(a) butanol/ asam asetat/ air (4:1:5); (b) etil asetat/ metanol/ air (6:4:2); (c) kloroform/ etil asetat/ asam formiat (0,5:9:0,5); (d) n-heksan/ etil asetat (4:1); (e) reagen anisaldehid dibawah sinar UV $365 \mathrm{~nm}$; $(f)$ reagen Dragendorf pada sinar tampak; $(g)$ reagen Liebermann-Burchard dibawah sinar UV $365 \mathrm{~nm}$; $(h)$ reagen $\mathrm{AlCl}_{3}$ dibawah sinar $U V 365 \mathrm{~nm}$

Caesalpinia sappan L. dikenal dengan nama umum pohon secang atau sepang. Spesies Caesalpinia ini adalah yang paling sering diteliti. Penelitian terhadap $C$. sappan menunjukkan bahwa ekstrak tumbuhan ini memiliki aktivitas antimikroba terhadap $S$. aureus, $P$. aeruginosa, Proteus vulgaris, Bacillus subtilis, Escherichia coli, dan Klebsiella pneumoniae. Ekstrak tumbuhan ini lebih menunjukkan aktivitas terhadap bakteri gram positif dibandingkan gram negatif (Mohan et al, 2011). Ekstrak etanol $C$. sappan juga menunjukkan aktivitas antimikroba terhadap Salmonella typhi, Streptococcus faecalis, S. pyogenes dan Enterobacter aerogenes (Srinivasan et al, 2012). Ekstrak air kayu batang C. sappan menunjukkan aktivitas antimikroba terhadap 5 bakteri patogen yang sering ditemukan di dalam rongga mulut, yaitu Enterococcus faecalis, Actinomyces viscosus, Streptococcus salivarius, $S$. mutans, dan S. sanguis (Keramat et al, 2014). Ekstrak C. sappan juga menunjukkan aktivitas antimikroba terhadap Propionibacterium acnes (Batubara dan Mitsunaga, 2013), dan ekstrak metanol batang $C$. sappan menunjukkan aktivitas antimikroba terhadap Clostridium perfringens (Zanin et al, 2012).

Penelitian lain menunjukkan bahwa zona inhibisi maksimal dari ekstrak $C$. sappan terdapat pada $P$. aeruginosa (34 $\mathrm{mm}$ ) disusul oleh $S$. aureus $(31 \mathrm{~mm}), S$. typhi $(24 \mathrm{~mm})$, E. aerogens $(21 \mathrm{~mm})$, dan E. coli $(15 \mathrm{~mm})$. Ekstrak metanol kulit batang $C$. sappan juga menunjukkan aktivitas penghambatan yang tinggi pada methicillin sensitive $S$. aureus (MSSA) dan methicillin resistant $S$. aureus (MRSA). Kandungan flavonoid dari ekstrak metanol $C$. sappan diduga berkaitan dengan aktivitas antibakteri terhadap MRSA (Nirmal et al, 2015). 
Skrining fitokimia ekstrak daun $C$. sappan menunjukkan adanya kandungan karbohidrat, glikosida, flavonoid, fenol, tanin dan asam amino (Kaur et al, 2016).

Brazilin yang merupakan hasil isolat dari komponen ekstrak C. sappan menunjukkan aktivitas antibakteri yang kuat terhadap MRSA, Vancomycinresistant Enterococci (VRE) dan Multidrug resistant Burkholderia cepacia. Mekanisme kerja aktivitas Brazilin terhadap MRSA diduga melalui penghambatan DNA dan sintesis protein. Brazilin juga menunjukkan aktivitas antimikroba yang kuat terhadap bakteri penyebab karies gigi ( $S$. mutans), bakteri penyebab penyakit periodontal (Prevotella intermedia) dan Streptococcus grup A (Nirmal et al, 2015). Brazilin yang merupakan komponen aktif dari $C$. sappan juga menunjukkan aktivitas antimikroba terhadap bakteri penyebab jerawat, yaitu P. acnes (Batubara et al, 2010).

Caesalpinia pulcherrima (L.) Sw. dikenal dengan nama umum pohon kembang merak. Spesies Caesalpinia ini cukup sering diteliti setelah $C$. sappan. Penelitian terhadap $C$. pulcherrima menunjukkan bahwa ekstrak metanol akar C. pulcherrima memiliki aktivitas antibakteri terhadap $K$. pneumonia (Prakash et al, 2009). Penelitian lain juga menunjukkan bahwa ekstrak daun $C$. pulcherrima memiliki aktivitas antimikroba terhadap bakteri Gram positive (S. aureus) dan Gram negatif ( $E$. coli, $K$. pneumoniae, dan $P$. aeruginosa) (Devi et al, 2012). Beberapa komponen seperti diterpenoid, peltoginoid, flavonoid, chalcone, dan homoisoflavonoid, telah berhasil diisolasi dari $C$. pulcherrima. Ekstrak buah $C$. pulcherrima menunjukkan aktivitas antimikroba terhadap $P$. vulgaris, $S$. aureus, dan $S$. faecalis. Homoisoflavoinoid yang diisolasi dari $C$. pulcherrima menunjukkan aktivitas antibakteri terhadap S. aureus, Klebsiella aerogenes, dan Chromobacterium violaceum. Isobonducelin yang diisolasi dari tumbuhan yang sama menunjukkan aktivitas antibakteri terhadap B. subtilis dan Chromobacterium violaceum. Furanic diterpenes isovouacapenol A-D yang diisolasi dari $C$. pulcherrima menunjukkan aktivitas antibakteri terhadap S. aureus dan B. subtilis (Zanin et al, 2012).

Berdasarkan penjelasan di atas, hasil penelitian ini serupa dengan penelitian yang dilakukan pada spesies Caesalpinia yang lain, yang mendukung hasil penelitian ini bahwa ekstrak daun $C$. sumatrana memiliki efek antimikroba terhadap $P$. aeruginosa, $P$. mirabilis, $S$. aureus dan MRSA.

\section{KESIMPULAN}

Hasil penelitian ini menunjukkan bahwa ekstrak etanol daun $C$. sumatrana yang digunakan oleh etnis Dayak di Kalimantan Timur berpotensi sebagai antimikroba terhadap bakteri penyebab infeksi nosokomial. Perlu adanya penelitian lanjutan agar tumbuhan obat ini dapat dikembangkan sebagai antibiotik baru untuk penatalaksanaan infeksi tersebut.

\section{DAFTAR PUSTAKA}

[1]. Batubara I, Mitsunaga T. (2013). Use of Indonesian Medicinal Plants Products Against Acne. Reviews in Agricultural Science. 1: 11-30.

[2]. Batubara I, Mitsunaga T, Ohashi H. (2010). Brazilin from Caesalpinia sappan wood as an antiacne agent. Journal Wood of Sciences. 56: 77-81.

[3]. Bonilla AR, Muniz KP. (2009). Antibiotic Resistance: Causes and Risk Factors, Mechanisms and Alternatives. Nova Science Publisher. New York.

[4]. Departemen Kesehatan RI. (2008). Farmakope Herbal Indonesia. Edisi Pertama. Departemen Kesehatan RI. Jakarta. 
Analisis bioautografi dengan kromatografi lapis tipis pada ekstrak etanol daun Caesalpinia sumatrana roxb. Terhadap bakteri penyebab infeksi nosokomial

[5]. Devi AS, Rajkumar J, Modilal MRD, Ilayaraja R. (2012). Antimicrobial activities of Avicennia marina, Caesalpinia pulcherrima and Melastoma malabathricum against clinical pathogens isolated from UTI. International Journal of Pharmacy and Biology Sciences. 3(3): (B) 698-705.

[6]. Ganapathy S, Karpagam S. (2016). In vitro evaluation of antibacterial potential of Andrographis paniculata against resistant bacterial pathogens Methicillin Resistant Staphylococcus aureus (MRSA) and Multiple Drug Resistant Escherichia coli (MDR E. coli). International Journal of Bioassays. 5(3): 4879-4881.

[7]. Ismail S, Suwasono RA, Supriyoko W, Kuswanto H, Paryono P. (2015). Laporan Penelitian Riset Eksplorasi Pengetahuan Lokal Etnomedisin dan Tumbuhan Obat di Indonesia Berbasis Komunitas di Suku Abai, Kabupaten Malinau, Propinsi Kalimantan Utara. Badan Penelitian dan Pengembangan Kesehatan. Kementerian Kesehatan RI.

[8]. Kaur H, Amini MH, Prabhakar PK, Singh A, Suttee A. (2016). Phytochemical Screening and Antimicrobial Activity of Caesalpinia sappan L. Leaves. International Journal of Pharmacognosy and Phytochemical Research. 8(6): 10401045.

[9]. Keramat H, Moaddabi A, Ranjbari A. (2014). In Vitro Antimicrobial Effects of Aqueous Extracts of Caesalpinia sappan Linn. Derivatives Against Oral Pathogen. Inidan Journal of Science Research. 7(1): 342-347.

[10]. Mohan G, Anand SP, Doss A. (2011). Efficacy of Aqueous and Methanol extracts of Caesalpinia sappan L. and Mimosa pudica L. for their potential Antimicrobial activity. South Asian Journal of Biology Sciences. 1(2): 48-47.
[11]. Nelson DL, Cox MM. (2005). Lehninger Principles of Biochemistry. Fourth Edition. 343-368. Freeman and Company. New York.

[12]. Nirmal NP, Rajput MS, Prasad RGSV, Ahmad M. (2015). Brazilin from Caesalpinia sappan heartwood and its pharmacological activities: A review. Asian Pacific Journal of Tropical Medicine. 8(6): 421-430.

[13]. Prakash SB, Sharmistha P, Kumar AR. (2009). Antibacterial Activity of Methanolic Extract of Roots of Caesalpinia pulcherrima. International Journal of Chemical Sciences. 7(1): 16-18.

[14]. Srinivasan R, Selvam GG, Karthik S, Mathivanan K, Baskaran R, Karthikeyan M, Gopi M. (2012). In vitro antimicrobial activity of Caesalpinia sappan L. Asian Pacific Journal of Tropical Biomedicine. S136-S139.

[15]. The Plant List. (2013). Version 1.1. http://www.theplantlist.org

[16]. World Health Organization. (2017 a). The burden of health care-associated infection worldwide.

http://www.who.int/gpsc/country work/bu rden_hcai/en/

[17]. World Health Organization. (2017 $\left.{ }^{\mathrm{b}}\right)$. WHO publishes list of bacteria for which new antibiotics are urgently needed. http://www.who.int/mediacentre/news/rele ases/2017/bacteria-antibiotics-needed/en/

[18]. Zanin JLB, de Carvalho BA, Martineli PS, dos Santos MH, Lago JHG, Sartorelli P, Viegas Jr C, Soares MG. (2012). The Genus Caesalpinia L. (Caesalpiniaceae): Phytochemical and Pharmacological Characteristics. Molecules. 17: 7887-7902. 